$1-1-1991$

\title{
Macrolepidopterous moths : collected by blacklight trap at Cooper's Rock State Forest, West Virginia : a baseline study
}

Linda Butler

Vicki Kondo

Follow this and additional works at: https://researchrepository.wvu.edu/ wv_agricultural_and_forestry_experiment_station_bulletins

\section{Digital Commons Citation}

Butler, Linda and Kondo, Vicki, "Macrolepidopterous moths : collected by blacklight trap at Cooper's Rock State Forest, West Virginia : a baseline study" (1991). West Virginia Agricultural and Forestry Experiment Station Bulletins. 705.

https://researchrepository.wvu.edu/wv_agricultural_and_forestry_experiment_station_bulletins/599 @ WVU. It has been accepted for inclusion in West Virginia Agricultural and Forestry Experiment Station Bulletins by an authorized administrator of

The Research Repository @WVU. For more information, please contact ian.harmon@mail.wvu.edu. 


\section{Macrolepidopterous Moths}

Collected by Blacklight Trap dtCooper's Rock State Forest, West Virginia: A Baseline Study 


\section{Authors}

Linda Butler is Professor of Entomology and Vicki Kondo is Entomology Research Assistant, Division of Plant and Soil Sciences, College of Agriculture and Forestry, West Virginia University.

This research was supported in part by a grant from the USDA Forest Service and in part from funds of the West Virginia Agricultural and Forestry Experiment Station. We would like to acknowledge the assistance of Dr. Edwin Townsend in data management.

West Virginia University

Agricultural and Forestry Experiment Station

College of Agriculture and Forestry

Robert H. Maxwell, Director

Morgantown 


\section{Macrolepidopterous Moths Collected by Blacklight Trap at Cooper's Rock State Forest, West Virginia: A Baseline Study}

\section{Linda Butler and Vicki Kondo}

\section{Introduction}

Lepidoptera, particularly Macrolepidoptera, have been the subject of considerable interest in recent years as indicators of bio-diversity and environmental balance. A number of Macrolepidoptera (primarily butterflies) are considered endangered or threatened, especially because of habitat destruction.

As the gypsy moth (Lymantria dispar L., Lymantriidae) moves into the central and southern Appalachians, concern grows for the possible impact of gypsy moth defoliation and suppression programs on non-target Lepidoptera. To determine such impacts, baseline data collected by appropriate sampling methods are essential.

Various types of light traps have long been used for control, survey or ecological studies of Macrolepidoptera. We report here the results of a three-year study of macrolepidopterous moths found at the West Virginia University Forest at Cooper's Rock State Forest, conducted to establish baseline data prior to build-up of gypsy moth populations. We also discuss use of blacklight trapping for baseline and non-target impact studies.

\section{Literature Review}

As early as 1879 , light traps were being used to collect insects (Comstock 1879). Williams (1939) listed three objectives in the use of light traps: (1) the collection of insect specimens to study distribution or taxonomy; (2) the study of insect ecology by evaluating numbers of captured specimens active at particular localities or dates and changes in populations due to climatic variation; and (3) a means of control for certain insects. Williams (1939) referred to numerous reports of light traps used for these purposes. 
An excellent summary of light-trap studies was presented by Hienton (1974), with a review of trap design changes over the years. Design standards for blacklight traps for insect surveys were given by Harding et al. (1966) and Smith et al. (1974). Light traps of many types have been compared for efficiency in capturing moths. Cantelo (1990) compared blacklight and Robinson mercury vapor traps for catch of agricultural pests. Frost (1957) compared insect captures taken with the Pennsylvania light trap with traps of other designs. Other comparative studies have been reported by Bretherton (1954), Vaishampayan and Verma (1983), Williams et al. (1955), Smith et al. (1959), Labanowski (1980), Waring (1980), Heath (1966) and Belton and Kempster (1963).

Light traps fitted with polarizing filters were more attractive to certain moths than traps without filters (Davidson et al. 1973). Light-trap collections of economically important moths increased when light traps were baited with phenylacetaldehyde (Cantelo and Jacobson 1979). Novak (1983) described a mercury vapor light trap incorporating an electrified wire grid for sampling moths of agricultural importance. A Texas-type trap equipped with electrodes was found to increase catch numbers and species numbers over traps without electrodes (Mizutani et al. 1982). Hollingsworth et al. (1961) showed that light-trap catches could be altered by enclosing traps with cylinders of hardware cloth of different mesh sizes. They also found that artificial wind breaks to shield traps from effects of prevailing wind increased trap catches. Ammar (1975) increased efficiency of light traps for catching small Lepidoptera and other insects by using wire mesh. Robinson and Robinson (1950) discussed the behavior of moths near light traps of various designs. A recent discussion of light-trap designs and their relationship to capture efficiency was given by Muirhead-Thomson (1991).

Light traps have been evaluated as control agents for various agricultural pests, particularly tomato and tobacco hornworm, European corn borer, cabbage looper, corn earworm and pink bollworm. A review of the subject was given by Cantelo (1974). Results of light trapping for control of economically important species have been mixed. In a three-and-one-half year study of mass trapping of moths isolated on St. Croix, U.S. Virgin Islands, Cantelo et al. (1974) noted that populations of several pest species of Sphingidae and Noctuidae declined. Williams (1939), however, noted no consistent decline in 150 species of Noctuidae and Geometridae, many of which were agricultural pests, that he collected in four years at Rothamsted, U.K. In further collections at the same location over a nine-year period, Taylor et al. (1978) recorded wide fluctuations, but no downward trends in species numbers.

Some arrangements or densities of light traps might increase pest numbers within an area. Debolt et al. (1979) stated that up to 14 times as many cabbage looper eggs were found in lightly trapped as in heavily trapped areas. 
Smith (1962) noted that a light trap at one location in Wisconsin appeared to stimulate an outbreak of armyworm by attracting moths into the area.

Extensive literature reports the use of light traps in survey of moths, particularly those of agricultural importance. Attempts have been made to use data to predict pest outbreaks, to forecast population trends, to time pesticide applications and to monitor effectiveness of controls. Light-trap surveys throughout the world have been instrumental in detecting new regional and national records from immigrant species of moths.

Light traps are valuable in many types of ecological and bionomical studies including flight phenology, migration patterns, long-distance flight capability, nocturnal flight time, sex ratios, voltinism, winter survival, reproductive potential and mating status. Morphological studies such as determination of melanism and insect wing length variations use light-trap collections.

The influence of weather on light-trap catches has been the subject of many studies; impact of moonphase, temperature, humidity, rainfall, wind and barometric pressure have been discussed. Light-trap captures are generally higher on warm, humid nights with no moonlight (McGeachie 1989).

A moth may reach a light trap by either chance or attraction; the distance over which attraction operates is highly dependent on light intensity and light wavelength (Hartstack 1979). Most researchers agree that the distance of positive attraction is no more than a few hundred feet. Obviously, this distance is also dependent on sex and species of moth, among other factors. Some species may disperse more widely during some years (as discussed by Sargent, 1976, for Catocala during periods of great abundance), and hence by chance may come within attraction distance of light traps. Baker and Sadovy (1978) used mark-release/recapture methods for estimating the distance of response of moths to a 125-watt mercury vapor light trap. They concluded that the response range of the two moth species studied was only about three meters. In tests with 15-watt blacklight traps, Manduca sexta (Johannson) (Sphingidae) exhibited attraction within $4.6 \mathrm{~m}$ of the radiation source, and for Heliothis zea (Boddie) (Noctuidae) the distance was $6.1 \mathrm{~m}$ (Stewart et al. 1969). In contrast, Spodoptera littoralis Boisduval (Noctuidae) was attracted to a 6-watt blacklight from at least $200 \mathrm{~m}$ (Plaut 1971).

Williams (1940) used light-trap catches of insects as a tool for estimating and forecasting changes in insect populations. He stated that it is possible to correct mean insect catch for each month for its variation from the normal due to changes in temperature, wind, and other factors. The result would be a value for what the catch would have been if all conditions had been normal for the month. The differences that remain, according to Williams, are due to population effects. King and Hind (1960) presented a method for the calculation of the theoretical catch level of insects taken in light traps. They 
suggested that departures from the theoretical catch are due to high or low activity and must be accounted for by weather. Williams (1940) discussed the concept that short-term (daily) variations in insect catch are functions of activity rather than population changes, and that long-term (seasonal or annual) variations in catch are functions of changing population rather than of activity.

Light trapping is a relative, not absolute, method of population estimation (Southwood 1978). In criticizing the use of light traps for population estimation, Taylor and Carter (1961) stated that the number of any species caught depends not only on their commonness but also on their attractedness to light. Taylor and French (1974) noted further that the relation between the catch and the parent population is not known, hence the catch cannot be treated as a true sample. They stressed the importance of selecting sampling sites as alike as possible if catches from different traps are to be compared.

Taylor and Brown (1972) noted that a light-trap catch represents a congregation at a point in space. They distinguished three different functions relating catch and space that may help to envisage the catch as a sample. They distinguished between local and migrant activity and discussed the concept of "area of influence" of the trap. White (1989) noted that the trappable area itself is rarely definable. Hartstack et al. (1968) used a series of oil-and-water-filled pans displayed around light traps to measure efficiency of traps. They concluded that large numbers of insects attracted to light traps are not caught. McGeachie (1988) used a video camera to estimate light-trap efficiency in the field. He divided insect flight tracks into three categories: (1) new arrivals, (2) passers by and (3) local flights. While trap efficiency varied with wind speed, he recorded a maximum of $39 \%$ efficiency in virtually calm conditions.

Sargent (1976) noted that the relative abundance of a species may vary considerably from year to year at a given location; the overall pattern of species abundance also varies over the years. Sargent's comments were made particularly regarding records of S.A. Hessel who light trapped Catocala spp. (Noctuidae) on virtually every night of twelve consecutive Catocala seasons. The variation in Hessel's data led Sargent to suggest the futility of making long-term assessments of populations based on records from a single season at any locality no matter how extensive collecting may be that season. Rejmanek and Spitzer (1982) reported results of a 12-year study of fluctuation in populations of noctuid moths in Bohemia. They discussed the relationship between species diversity and species stability in Lepidoptera communities monitored by light trapping.

Spitzer and Leps (1988) studied year-to-year variation in abundance of noctuid moths in three Central European habitats differing in successional status and degree of disturbance. Highest variation was found in moth species with a high population growth rate. Climax habitats supported 
populations of moths with low variation in abundance and low population growth rate.

White (1989) discussed the concept of "dilution ratios" of moths as their numbers are reduced due to frequent trapping. Thomas (1989) noted that the optimum frequency for light trapping at a given site was every third to seventh night. He stated that with care, light trapping and live release can provide valid population indices for comparison between generations and years for a given moth species.

Placement of light traps greatly influences moth catch. Hausmann (1990a) found that two light traps located only $45 \mathrm{~m}$ apart showed great differences in species composition. He noted that the method of using single light traps has to be regarded as site specific and must be considered in ecological interpretations of data. Williams et al. (1955) discussed the importance of rotating traps among designated trapping sites to minimize effects of differences among traps.

In a study comparing light-trap catches in deciduous and coniferous woodland habitats, Waring (1989) warned that woodland studies are especially challenging because of the amount of shading and screening of light traps by vegetation. He stressed the need for carefully choosing light-trap sites. Magurran (1985) studied differences in Macrolepidoptera in Ireland and noted that insect diversity can be correlated with site factors, but as the relationship is a very complex one, such correlations should be interpreted with great care.

Mizutani (1982) arranged 10 light traps in a line at regular intervals of $28.6 \mathrm{~m}$ between two forests about $200 \mathrm{~m}$ apart. He found that catches of moths were greatest in numbers of species and individuals within about 30 $\mathrm{m}$ from the forest edge and concluded that $30 \mathrm{~m}$ from the forest edge is the most suitable placement for a light trap.

A number of studies have been conducted on the use of light traps to evaluate the Macrolepidoptera community at a single site over a period of several years. Dirks (1937) recorded 344 species of Macrolepidoptera collected over a four-year period at one site in Orono, Maine. During his studies at Rothamsted, Williams (1939) collected 356 species over four years. The Rothamsted insect survey, which includes moth monitoring, has continued since 1969. A history of the survey was given by Taylor (1979). During six years of blacklight-trap collections at Archbold Biological Station in Florida, Frost (1964) captured 330 Macrolepidoptera species. In a recent study of a New Jersey oak forest, Moulding and Madenjian (1979) recorded 410 species over a five-year period.

Rings et al. (1987) conducted a nine-year study of the Lepidoptera of the Wilderness Center, Stark County, Ohio, and recorded 426 species of macrolepidopterous moths. In similar studies at Atwood Lake Park, Mohican State Forest and State Park and Fowler Woods, Ohio, Rings and 
Metzler (1988, 1989, 1990) listed 382, 417 and 374 forms and species of macrolepidopterous moths, respectively. Sampling methods for these studies included ultraviolet light traps, mercury vapor light, bait traps, sugaring and netting.

Holloway (1984) advocated the use of light-trap sampling of moths as a means of indicating response of rain forest insect communities to disturbance. He concluded that this simple and quick approach uses elements of the fauna that are easily sampled, widely distributed, diverse, show specificity to vegetation type, and are sensitive to change.

Recent and ongoing studies are being conducted in the eastern United States using light trapping to establish baseline data and to evaluate impact of gypsy-moth defoliation or sprays applied as a part of gypsy-moth suppression programs. Peacock and Bullington (1989) recently conducted a study on effects of Bacillus thuringiensis Berliner var. kurstaki on native Lepidoptera in the Shenandoah National Park, Virginia, using blacklight traps to monitor moth populations. They noted that total season capture of selected species in treated and untreated areas was extremely variable, prohibiting any legitimate analysis of the data.

Sample (1991) recently completed a study of diflubenzuron impact on non-target insects as food of the Virginia big-eared bat in West Virginia. Blacklight traps operated in seven pairs of treated and untreated plots were the primary sampling tools. Sample found that total species richness and species richness in four of eight Lepidoptera families was reduced. Of the 83 macrolepidopterous species in sufficient abundance for statistical analysis, 47 were significantly reduced.

In an ongoing study in the Great Smoky Mountains National Park, Watson and Lambdin (1989) are collecting baseline data on Lepidoptera prior to buildup of gypsy-moth populations. Blacklight traps are being used to collect samples from 10 permanent sites, five each in North Carolina and Tennessee.

Light trapping of insects has provided valuable information on insect distribution, taxonomy, ecology, and control for more than a century. Currently, light traps are particularly useful tools for establishing baseline data and for measuring impacts due to forest disturbance by pesticide spraying.

\section{Materials and Methods}

This study was conducted at the West Virginia University Forest at Cooper's Rock State Forest, located in Preston and Monongalia counties about $32 \mathrm{~km}$ east of Morgantown, West Virginia. The area consists of a 50to 60-year old even-aged mixed mesophytic forest and has a mean elevation of $561 \mathrm{~m}$ (Carvell 1983). Near the light trapping site the canopy is white and red oak (Querus alba L, Q. rubra L., Fagaceae) and the understory is red 
maple (Acer rubrum L., Aceraceae), black cherry (Prunus serotina Ehrh., Rosaceae) and black birch (Betula lenta L., Betulaceae). The light-trap site was approximately $200 \mathrm{~m}$ from the nearest significant clearing, Sand Spring Road, and was at coordinates $39^{\circ} 40^{\prime}$ North latitude by $79^{\circ} 47^{\prime}$ West longitude.

From mid-March to late October 1984-1986, a single blacklight trap was operated one night each week. The trap was a 15-watt, photo-cell-controlled UV type (Ellisco Co., Philadelphia) set on tripod legs. Trap nights were chosen to avoid unseasonably low temperatures when possible, but no attempt was made to avoid rainy nights.

Macrolepidopterous moths were identified by comparison with the West Virginia University Arthropod Collection; counts were made for each species. Voucher specimens from the study are deposited in the WVU Arthropod Collection. Species are named and listed after the checklist given by Hodges et al. (1983).

\section{Results}

From 1984 to 1986, 400 species of macrolepidopterous moths in 13 families were captured in one blacklight trap operated at a single site at Cooper's Rock State Forest (Tables 1 and 2). The Noctuidae contributed 220 species and the Geometridae 102 species. Considerable variation in frequency and abundance of species occurred among the three years. This variation was especially evident in the Noctuidae; for example, while 220 species were trapped during the three-year study, only 81 of those species were trapped all three years. Sixty-two species were trapped only two of the three years, and 77 were collected only one year during the study (Table 1).

Table 2 lists the 400 species, giving total catch for each year. Each species is ranked with regard to relative abundance each year. The inclusive flight range for all three years from date of first capture to date of last capture is included. The most abundant species were the geometrids Itame pustularia, Probole amicaria, Lomographa glomeraria, Melanolophia canadaria and Campaea perlata. Other abundant species were Halysidota tesselaris and Clemensia albata (Arctiidae); Malacosoma americanum (Lasiocampidae); Orthodes cynica, Idia aemula and Zanclognatha ochreipennis (Noctuidae) and Nadata gibbosa, Heterocampa guttivitta, and Peridea angulosa (Notodontidae).

Considerable fluctuation in abundance of many species occurred from year to year. Counts for Hyphantria cunea (Arctiidae) were 153 and 169 for 1984 and 1985, respectively; only 13 specimens were captured in 1986. Halysidota tessellaris (Arctiidae) counts dropped from 698 in 1984 to 149 in 1985. Pero honestaria (Geometridae) declined from 89 (1984) to 23 (1985) to 0 (1986). Besma quercivoraria (Geometridae) captures dropped from 279 to 114 to 25. In 1984, 173 Orygia leucostigma (Lymantriidae) were captured, 
dropping to 37 in 1985 and rebounding to 163 in 1986. Idia aemula (Noctuidae) catches declined from 346 in 1984 to 38 in 1985. Zanclognatha laevigata and $Z$. ochreipennis (Noctuidae) both showed a three-fold decline in counts from 1984 to 1985. Counts for Morrisonia confusa (Noctuidae) were 79 (1984), 119 (1985) and 0 (1986). Peridea angulosa (Notodontidae) counts dropped from 192 in 1984 to 59 in 1985.

While many species showed dramatic declines in trapped numbers from 1984 to 1986, some species increased. Counts for Probole amicaria (Geometridae) increased from 133 (1984) to 1073 (1985). Only 61 Heterocampa guttivitta (Notodontidae) were trapped in 1984, while 297 were taken in 1986. During that time, Nadata gibbosa (Notodontidae) counts also increased from 77 to 240. Counts of some species, such as Melanolophia canadaria (Geometridae) and Lomographa glomeraria (Geometridae) remained rather stable during the three-year period.

Dates on flight range (Table 2) are given as earliest catch and latest catch for the three years combined. Variation in length of flight season among species reflects varying degrees of synchrony of adult emergence, differences in adult longevity, effect of multivoltine versus univoltine species and population levels. In general, longer flight seasons are shown for species at higher populations since greater numbers would give greater variation in emergence and longevity.

Examples of multivoltine species are Melanolophia canadaria (Geometridae), Campaea perlata (Geometridae) and Lomographa glomeraria (Geometridae), all of which showed relatively high populations and long flight season. Polia latex (Noctuidae) is an example of a univoltine species with a long flight season reflecting high populations and relative lack of synchrony of adult emergence. Lithophane hemina (Noctuidae) is an example of a species that emerges in the autumn and overwinters as an adult. Moths of different generations are picked up in light traps operated from March through October, but the species is univoltine.

\section{Discussion}

The study site at Cooper's Rock State Forest has a highly diverse population of Macrolepidoptera. We collected 400 species of moths at a single blacklight trap site, a higher number than reported in other studies. Where more species were recorded, several different light trap sites were used and/or sampling methods in addition to blacklight traps were employed.

As indicated in Table 1, species richness fluctuated dramatically over the three years of the study. Hausmann (1990b) noted that in a two-year study of light-trapped moths near Munich, Germany, the "species spectra" covered by one light trap showed a year-to-year turnover of $35 \%-55 \%$. The yearly turnover in our study falls within this expected range. 
The results of our study and reports of others cited in this paper can give us some guidance on use of light traps in conducting baseline studies or in determining non-target impacts of insecticides or some other disturbance. We recommend consideration of the following items:

- Collect as many years of baseline data as possible to gain insight into expected "normal fluctuation" of light-trapped moths from year to year. Operate as many light traps as possible over the study area so that variation will even out among sites and over years. Disturbed sites, by their nature, are likely to show wider fluctuations in populations from year to year (Spitzer and Leps 1988).

- Do not operate traps too frequently at each site. Thomas (1989) suggested that trapping every three to seven nights was optimum. If traps are operated less frequently than every two weeks, some moth species, especially those in low populations, may not be captured.

- Carefully choose light-trap sites if data from traps on different sites are to be compared. Waring (1989) noted that woodland studies are especially challenging because of shading and screening by vegetation. Conducting vegetation analysis and pairing sites with similar vegetational composition for light-trap comparison is desirable. Using this method Sample (1991) strengthened his study in use of light traps to determine Dimilin impact on moths as food for the Virginia big-eared bat.

- Rotate traps among sites at each sampling period to avoid bias due to trap differences. Operate light traps simultaneously on as many study sites as possible to avoid the additional variable of different weather conditions on trapping results.

- Use sufficiently large study plots to avoid attracting moths from outside plots. Plaut (1971) noted that some noctuids may be attracted from 200 $\mathrm{m}$. Small plots also allow immigration and emigration of more actively flying moths. Once moths move into a plot from the surrounding matrix, they then may be attracted to traps, thus obscuring treatment effects in the study plots.

With proper precautions, light traps are a useful tool for studying non-target disturbance impacts on moths. We do not use traps to define populations, but need to be concerned only with relative differences among trap sites as affected by treatments.

\section{Summary}

A single blacklight trap was operated weekly at Cooper's Rock State Forest, West Virginia from March to October 1984-1986. Four hundred species of Macrolepidoptera were taken. Yearly fluctuation was considerable among many of the species. A review of literature on blacklight trapping studies is presented. 


\section{Literature Cited}

Ammar, E.D. 1975. A light trap modified for catching only smaller insects and its efficiency in catching certain groups compared with a sweeping net. Zeits. Angew. Entomol. 79:104-109.

Baker, R.R. and Y.S. Sadovy. 1978. The distance and nature of the light trap response of moths. Nature, London: 276:818-821.

Belton, P. and R.H. Kempster. 1963. Some factors affecting the catches of Lepidoptera in light traps. Can. Entomol. 95:832-837.

Bretherton, R.F. 1954. Moth traps and their lamps: an attempt at comparative analyses. Entomol. Gaz. 5:145-154.

Cantelo, W.W. 1974. Blacklight traps as control agents: an appraisal. Bull. Entomol. Soc. Amer. 20: 279-282.

Cantelo, W.W. 1990. Comparative efficiency of a blacklight trap and a Robinson trap in trapping moths. Southwest. Entomol. 15:159-162.

Cantelo, W.W., J.L. Goodenough, A.H. Baumhover, J.S. Smith, Jr., J.M. Stanley and T.J. Henneberry. 1974. Mass trapping with blacklight: effects on isolated populations of insects. Environ. Entomol. 3:389-395.

Cantelo, W.W. and M. Jacobson. 1979. Phenylacetaldehyde attracts moths to bladder flower and to blacklight traps. Environ. Entomol. 8:444-447.

Carvell, K.L. 1983. A summary of 1973-1982 weather data from the West Virginia University Forest. W.Va. Forestry Notes 10:13-16.

Comstock, J.H. 1879. Fires, trap-lanterns, etc. pp. 262-275. In Report on Cotton Insects. USDA Dir. Entomol. Washington, D.C.

Davidson, A., J.E. Gallagher and H.S. Hsiao. 1973. Reactions of some moths and aquatic insects to light traps fitted with polarizing filters. Ann. Entomol. Soc. Amer. 66:232-233.

Debolt, J.W., W.W. Wolf, T.J. Henneberry and P.V. Vail. 1979. Evaluation of light traps and sex pheromones for control of cabbage looper and other lepidopterous insect pests of lettuce. USDA Tech. Bull. No. 1606, 39 pp.

Dirks, C.O. 1937. Biological studies of Maine moths by light trap methods. Maine Agric. Expt. Stn. Bull. 389.

Frost, S.W. 1957. The Pennsylvania insect light trap. J. Econ. Entomol. 50:287-292.

Frost, S.W. 1964. Insects taken in light traps at the Archbold Biological Station, Highlands County, Florida. Fla. Entomol. 47:129-161. 
Harding, W.C., Jr., J.G. Hartsock and G.G. Rohwer. 1966. Blacklight trap standards for general insect surveys. Bull. Entomol. Soc. Amer. 12:31-32.

Hartstack, A.W. 1979. Light sources, trap design and other factors affecting moth catch. Chap. 15. In Movement of Highly Mobile Insects: Concepts and Methodology in Research. Ralb, R.L. and G.G. Kenedy (eds.), 456 pp.

Hartstack, A.W., Jr., J.P. Hollingsworth and D.A. Lindquist. 1968. A technique for measuring trapping efficiency of electric insect traps. J. Econ. Entomol. 61:546-552.

Hausmann, A. 1990a. Die Bedeutung des genauen Lichtfallen-Standortes für die Aussagekraft des Fangergebnisses. Atalanta 21:301-312.

Hausmann, A. 1990b. Zur Dynamik von Nachfalter Artenspektren Verhalten als Elemente von Verbreitungsstrategien. Spixiana. Zeits. Zool. 16, 222 pp.

Heath, J. 1966. A comparison of catches obtained in insect light traps fitted with 16 watt and 6 watt blacklight fluorescent tubes. Entomol. Record 78: 222-223.

Hienton, T.E. 1974. Summary of investigations of electric insect traps. USDA tech. Bull 1498, 136 pp.

Hodges, R.W., T. Dominic, D.R. Davis, D.C. Ferguson, J.G. Franclemont, E.G. Monroe and J.A. Powell. 1983. Checklist of the Lepidoptera of America North of Mexico. London. E.W. Classey Ltd. and Washington, D.C. Wedge Entomol. Res. Found. 284 pp.

Hollingsworth, J.P., C.P. Briggs, III, P.A. Glick and H.M. Graham. 1961. Some factors influencing light trap collections. J. Econ. Entomol. 54:305308.

Holloway, J.D. 1984. Moths as indicator organisms for categorizing rainforest and monitoring changes and regeneration processes. Tropical Rain Forest: The Leeds Symposium, pp. 235-242.

King, E.W. and A.T. Hind. 1960. Activity and abundance in insect light trap sampling. Ann. Entomol. Soc. Amer. 53:524-529.

Labanowski, G.S. 1980. Catches of moths in the blacklight and mercuryfilament traps in an orchard at Skierniewice, Poland. Pulsk. Pismo Entomol. 50:473-487.

Magurran, A.E. 1985. The diversity of Macrolepidoptera in two contrasting woodland habitats at Banagher, Northern Ireland. Proc. Roy. Irish Acad., Sect. B, Biol., Geol. and Chem. Sci. 85:121-132. 
McGeachie, W.J. 1988. A remote sensing method for the estimation of light trap efficiency. Bull. Entomol. Res. 78:379-385.

McGeachie, W.J. 1989. The effects of moonlight illuminance, temperature and wind speed on light-trap catches of moths. Bull. Entomol. Res. 79:185192.

Mizutani, M. 1982. Optimum setting position of the light trap for the collection of moths (Lepidoptera). Jap. J. Appl. Entomol. Zool. 26:58-62.

Mizutani, M., J. Mishima and Y. Kobayashi. 1982. The electrode type light trap for the collection of moths. App. Entomol and Zool. 17:172-178.

Moulding, J.D. and J.J. Madenjian. 1979. Macrolepidopteran moths lighttrapped in a New Jersey oak forest (Lepidoptera). Proc. Entomol. Soc. Wash. 81:135-144.

Muirhead-Thomson, R.C. 1991. Trap responses of flying insects. The influence of trap design on capture efficiency. Academic Press, San Diego. 304 pp.

Novak, I. 1983. An efficient light-trap for catching insects. Acta Entomol. Bohemoslovica. 80:29-34.

Peacock, J.W. and S.W. Bullington. 1989. Evaluation of the impact of Bacillus thuringiensis on non-target Lepidoptera in the Shenandoah National Park. Proc. 1989 Nat. Gypsy Moth Rev. Nov. 6-9, 1989, Annapolis.

Plaut, H.N. 1971. Distance of attraction of moths of Spodoptera littoralis to $B L$ radiation, and recapture of moths released at different distance of an ESA blacklight standard trap. J. Econ. Entomol. 64:1402-1404.

Rejmanek, M. and K. Spitzer. 1982. Bionomic strategies and long-term fluctuations in abundance of Noctuidae (Lepidoptera). Acta Entomol. Bohemoslovica 79:81-96.

Rings, R.W. and E.H. Metzler. 1988. Preliminary annotated checklist of the Lepidoptera of Atwood Lake Park, Ohio. Ohio J. Sci. 88:59-168.

Rings, R.W. and E.H. Metzler. 1989. A preliminary checklist of the Lepidoptera of Mohican State Forest and Mohican State Park, Ashland County, Ohio. Ohio J. Sci. 89:78-88.

Rings, R.W. and E.H. Metzler. 1990. The Lepidoptera of Fowler Woods State Nature Preserve, Richland County, Ohio. The Great Lakes Entomol. 23:43-56. 
Rings, R.W., R.M. Rittles, R.W. Hawes and E.H. Metzler. 1987. A nine-year study of the Lepidoptera of the Wilderness Center, Stark County, Ohio. Ohio J. Sci. 87:55-61.

Robinson, H.S. and P.J.M. Robinson. 1950. Some notes on the observed behavior of Lepidoptera in flight in the vicinity of light-trap sources together with a description of a light trap designed to take entomological samples. Ent. Gaz. 1:3-20.

Sample, Bradley E. 1991. Effects of Dimilin on food of the endangered Virginia big-eared bat. Ph.D. Dissertation, West Virginia University. 201 pp.

Sargent, T.D. 1976. Legion of Night - The Underwing Moths. Univ. Massachusetts Press, Amherst. 222 pp.

Smith, J.S., Jr., J.M. Stanley, J.G. Hartsock and L.E. Campbell. 1974. S-1 Black-light insect-survey trap, plans and specifications. USDA, ARS-S-31, 8 pp.

Smith, P.W. 1962. The use of blacklight insect traps as an entomological tool. Proc. N. Central Branch - E.S.A. 17:38-39.

Smith, P.W., J.G. Taylor and J.W. Apple. 1959. A comparison of insect traps equipped with 6- and 15-watt blacklight lamps. J. Econ. Entomol. 52:12121214.

Southwood, T.R. E. 1978. Ecological methods with particular reference to the study of insect populations. 2nd Edition. Wiley \& Sons, New York. 524 pp.

Spitzer, K. and J. Leps. 1988. Determinants of temporal variation in moth abundance. Oikos 53:31-36.

Stewart, P.A., J.J. Lam, Jr. and J.L. Blythe. 1969. Influence of distance on attraction of tobacco hornworm and corn earworm moths to radiations of a blacklight lamp. J. Econ. Entomol. 62:58-60.

Taylor, L.R. 1979. The Rothamsted insect survey - an approach to the theory and practice of synoptic pest forecasting in agriculture. In Movement of Highly Mobile Insects: Concepts and Methodology in Research. R.L. Rabb and G.G. Kennedy, Eds. pp. 148-185.

Taylor, L.R. and E.S. Brown. 1972. Effects of light-trap design and illumination on samples of moths in the Kenya highlands. Bull. Entomol. Res. 62:91-112. 
Taylor, L.R. and C.I. Carter. 1961. The analysis of numbers and distribution in an aerial population of Macrolepidoptera. Trans. Roy. Entomol. Soc. London 113: 369-386.

Taylor, L.R. and R.A. French. 1974. Effects of light-trap design and illumination on samples of moths in an English woodland. Bull. Entomol. Res. 63:593-594.

Taylor, L.R., R.A. French and I.P. Woiwod. 1978. The Rothamsted insect survey and the urbanization of land in Great Britain, pp. 31-66. In Frankie, G.W. and C.S. Koehler (eds.), perspectives in urban entomology. Academic Press, New York. 417 pp.

Thomas, C.D. 1989. Limits and scope of light-trapping for studying moth population dynamics. New Zealand Entomol. 12:89-90.

Vaishampayan, S.M. and R. Verma. 1983. Comparative efficiency of various light sources in trapping adults of Heliothis armigera (Hubn.), Spodoptera litura (Boisd.) and Agrotis ipsilon (Hufn.) (Lepidoptera: Noctuidae). Indian J. Agric. Sci. 53:163-167.

Waring, P. 1980. A comparison of the Heath and Robinson M.V. traps. Entomol. Record 92:283-289.

Waring, P. 1989. Comparison of light-trap catches in deciduous and coniferous woodland habitats. Entomol. Record 101:1-10.

Watson, J.K. and P.L. Lambdin. 1989. Diversity of lepidopteran fauna collected from selected sites throughout the Great Smoky Mountains National Park. Proc. 1989. Nat. Gypsy Moth Rev. Nov. 6-9, 1989, Annapolis.

White, E.G. 1989. Light-trapping frequency and data analysis - a reply. New Zealand Entomol. 12:91-94.

Williams, C.B. 1939. An analysis of four years of captures of insects in a light trap. Part I. General survey; sex proportion; phenology; and time of flight. Trans. Roy. Entomol. Soc. London 87:79-131.

Williams, C.B. 1940. An analysis of four years captures of insects in a light trap. Part II. The effect of weather conditions on insect population. Trans. Roy. Entomol. Soc. London 90:227-306.

Williams, C.B., R.A. French and M.M. Hosni. 1955. A second experiment on testing the relative efficiency of insect traps. Bull. Entomol. Res. 46:193204. 
TABLE 1.

Number of species of Macrolepidoptera in all families taken by blacklight trap at Cooper's Rock State Forest, West Virginia (1984-1986) during any one, two or three years of the study.

FAMILY

\begin{tabular}{|c|c|}
\hline $\begin{array}{l}\text { \# of YEARS } \\
\text { Species Trapped }\end{array}$ & $\begin{array}{l}\text { TOTAL } \\
\text { SPECIES }\end{array}$ \\
\hline 12 & \\
\hline
\end{tabular}

THYATIRIDAE 3

DREPANIDAE 2012

\begin{tabular}{lllll}
\hline GEOMETRIDAE & 20 & 22 & 60 & 102
\end{tabular}

\begin{tabular}{lll}
\hline EPIPLEMIDAE & 1 & 1
\end{tabular}

\begin{tabular}{llll}
\hline MIMALLONIDAE & 1 & 1 & 2
\end{tabular}

\begin{tabular}{llll}
\hline APATELODIDAE & 1 & 1 & 2
\end{tabular}

\begin{tabular}{llll}
\hline LASIOCAMPIDAE & 1 & 3 & 4
\end{tabular}

\begin{tabular}{llll}
\hline SATURNIIDAE & 2 & 4 & 6
\end{tabular}

\begin{tabular}{lllll}
\hline SPHINGIDAE & 1 & 3 & 2 & 6
\end{tabular}

\begin{tabular}{lllll}
\hline NOTODONTIDAE & 10 & 2 & 19 & 31
\end{tabular}

\begin{tabular}{lllll}
\hline ARCTIIDAE & 6 & 5 & 6 & 17
\end{tabular}

\begin{tabular}{lllll}
\hline LYMANTRIIDAE & 1 & 1 & 2 & 4
\end{tabular}

\begin{tabular}{lllll}
\hline NOCTUIDAE & 77 & 62 & 81 & 220
\end{tabular}

\begin{tabular}{lllll}
\hline TOTAL SPECIES & 116 & 99 & 185 & 400
\end{tabular}




\section{TABLE 2.}

Macrolepidoptera species collected by blacklight trap at Cooper's Rock State Forest, West Virginia during 1984-1986. Total catch numbers, rank and inclusive flight range are given.

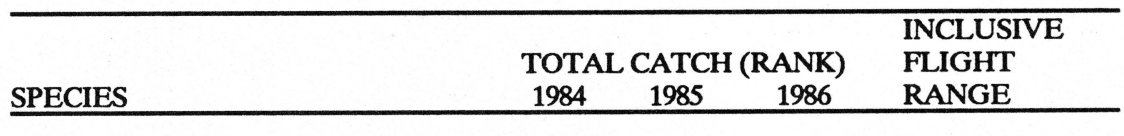

THYATIRIDAE

Habrosyne scripta (Gosse)

Pseudothyatira cymatophoroides (Gn.)

Euthyatira pudens (Gn.)

\section{DREPANIDAE}

Drepana arcuata Wlk.

Oreta rosea (Wlk.)

\section{GEOMETRIDAE}

Heliomata cycladata G.\& R.

Itame pustularia $(\mathrm{Gn}$.)

Semiothisa aemulataria (W1k.)

Semiothisa ulsterata (Pears.)

Semiothisa pinistrobata Fgn.

Semiothisa ocellinata (Gn.)

Enconista dislocaria (Pack.)

Glena cribrataria (Gn.)

Aethalura intertexta (Wlk.)

Iridopsis larvaria (Gn.)

Anavitrinelia pampinaria (Gn.)

Cleora sublunaria (Gn.)

Ectropis crepuscularia (D.\& S.)

Protoboarmia porcelaria (Gn.)

Epimecis hortaria (F.)

Melanolophia canadaria (Gn.)

Biston betularia (L.)

Hypagyrtis unipunctata (Haw.)

Phigalia titea (Cram.)

Paleacrita vernata (Peck)

Paleacrita merriccata Dyar

Erannis tiliaria (Harr.)

Lomographa semiclarata (Wlk.)

Lomographa vestaliata (Gn.)

Lomographa glomeraria (Grt.)

Cabera erythemaria $\mathbf{G n}$.

Cabera quadrifasciaria (Pack.)

Lytrosis unitaria (H.-S.)

Euchlaena serrata (Drury)

Euchlaena obtusaria (Hbn.)

$\begin{array}{rrrl}2(215) & 14(102) & 5(134) & 24 \mathrm{MAY}-15 \mathrm{AUG} \\ 4(179) & 3(179) & 11(95) & 29 \mathrm{MAY}-13 \mathrm{SEP} \\ 2(215) & 12(111) & 2(184) & 15 \mathrm{APR}-12 \mathrm{MAY}\end{array}$

$\begin{array}{rrrr}11(130) & 6(151) & 22(64) & \text { 10MAY-11SEP } \\ 18(95) & 8(131) & 4(147) & 30 \mathrm{MAY}-24 S E P\end{array}$

\begin{tabular}{|c|c|c|c|}
\hline $4(179)$ & $3(179)$ & $6(124)$ & $05 \mathrm{JL}$ \\
\hline $49(1)$ & 588( & $337(5)$ & 11SEP \\
\hline 39 ( 29) & $101(27)$ & $30(58)$ & 11SEP \\
\hline $44(61)$ & $96(28)$ & $16(76)$ & $5 A U C$ \\
\hline $3(191)$ & 0 & $57(39)$ & $06 \mathrm{JU}$ \\
\hline $25(83)$ & $1(224)$ & $8(106)$ & $12 \mathrm{M}$ \\
\hline $13(115)$ & $8(131)$ & $3(161)$ & 3JUN \\
\hline $18(95)$ & $23(78)$ & $65(34)$ & 6JUL \\
\hline $1(242)$ & $6(151)$ & $6(124)$ & 7JUL \\
\hline $65(15)$ & $195(9)$ & $119(20)$ & SEP \\
\hline $15(104)$ & $7(141)$ & $7(116)$ & 1SEP \\
\hline $2(215)$ & $1(224)$ & & 2MAY \\
\hline & $73(36)$ & $43(46)$ & AUG \\
\hline $54(50)$ & $6(151)$ & 0( & $12 \mathrm{M}$ \\
\hline $50(54)$ & $120(21)$ & $127(18)$ & SEP \\
\hline $497(4)$ & $624(2)$ & 553( & CT \\
\hline $70(41)$ & $63(42)$ & $22(64)$ & 1SEP \\
\hline $60(46)$ & $40(55)$ & $37(48)$ & 4SEP \\
\hline $11(130)$ & $12(111)$ & $15(79)$ & $28 \mathrm{M}$ \\
\hline $1(242)$ & $3(179)$ & $5(134)$ & 12APR \\
\hline & & $3(161)$ & MAR \\
\hline $3(191)$ & $2(199)$ & $3(161)$ & NOV \\
\hline $2(215)$ & $4(163)$ & $1(212)$ & 10JUL \\
\hline $18(95)$ & $133(18)$ & $236(8)$ & -07AUG \\
\hline $519(3)$ & 5381 & 584( & 25MAY \\
\hline 0( & $15(96)$ & $16(76)$ & 16MA \\
\hline & $1(224)$ & 0 & -10JUL \\
\hline $10(136)$ & $3(179)$ & $27(60)$ & $18 J U L$ \\
\hline $0(\quad)$ & $4(163)$ & $5(134)$ & $27 \mathrm{JUN}$ \\
\hline $15(104)$ & $1(224)$ & $0(\quad)$. & $22 \mathrm{JUN}-1$ \\
\hline
\end{tabular}




\begin{tabular}{|c|c|c|c|c|}
\hline SPECIES & \multicolumn{3}{|c|}{ TOTAL CATCH (RANK) } & $\begin{array}{l}\text { INCLUSIVE } \\
\text { FLIGHT } \\
\text { RANGE }\end{array}$ \\
\hline Euchlaena johnsonaria (Fitch) & & $1(224)$ & 0( & 05JUN-05JUN \\
\hline Euchlaena marginaria (Minot) & $5(166)$ & $2(199)$ & 0 & 10MAY-08JUN \\
\hline Euchlaena tigrinaria (Gn.) & $10(136)$ & $7(141)$ & $3(161)$ & 05JUN-28JUN \\
\hline Euchlaena irraria (B.\& McD.) & $10(136)$ & $2(199)$ & $2(184)$ & $12 \mathrm{JUN}-28 \mathrm{JUN}$ \\
\hline Xanthotype sospeta (Drury) & 1(242) & 1(224) & $2(184)$ & 05JUN-05SEP \\
\hline Pero honestaria (Wlk.) & $89(29)$ & $23(78)$ & 0( & 25APR-23AUG \\
\hline Pero morrisonaria (Hy. Edw.) & $22(88)$ & $73(36)$ & $29(59)$ & 05JUN-30JUL \\
\hline Nacophora quernaria (J.E. Smith) & $13(115)$ & $16(94)$ & $22(64)$ & 16MAY-27JUL \\
\hline Campaea perlata (Gn.) & $153(16)$ & $121(20)$ & $461(4)$ & 29MAY-02OCT \\
\hline Ennomos magnaria Gn. & $20(91)$ & $45(51)$ & $48(43)$ & 24SEP-22OCT \\
\hline Homochlodes disconventa (Wlk.) & $108(24)$ & $52(47)$ & $64(36)$ & 15APR-01OCT \\
\hline Selenia kentaria (G.\& R.) & $3(191)$ & $9(125)$ & $0()$. & 19APR-08AUG \\
\hline Metanema inatomaria (Gn.) & & 0( & $2(184)$ & 06JUN-10JUL \\
\hline Metarranthis dua & $7(154)$ & $10(120)$ & $5(134)$ & 19APR-08JUN \\
\hline Metarranthis angularia & $0(\quad)$. & $0(\quad)$. & $7(116)$ & $06 \mathrm{JUN}-12 \mathrm{JUN}$ \\
\hline Metarranthis hypocharia (H.-S.) & $75(36)$ & $49(49)$ & $1(212)$ & 23MAY-28JUN \\
\hline Metarranthis homuraria & $0(\quad)$. & $O(\quad)$. & $18(73)$ & 06JUN-20JUN \\
\hline Cepphis armataria (H.\& S.) & $5(166)$ & $4(163)$ & $12(91)$ & 12JUN-30JUL \\
\hline Anagoga occiduaria (Wlk.) & $73(40)$ & $9(125)$ & $3(161)$ & 25APR-15AUG \\
\hline Probole alienaria (H.-S.) & $80(33)$ & $15(96)$ & 0( & 10MAY-06JUL \\
\hline Probole & $133(19)$ & $1073(1)$ & $580(2)$ & 06MAY-23AUG \\
\hline Plagodis serinaria H.-S. & $74(39)$ & $173(12)$ & $77(32)$ & 16MAY-28JUN \\
\hline Plagodis phlogosaria (Gn.) & $24(84)$ & $5(157)$ & $3(161)$ & 10MAY-08AUG \\
\hline Plagodis fer & $8(149)$ & $2(199)$ & 0( & 03JUN-08AUG \\
\hline Plagodis alcoolaria (Gn.) & $111(23)$ & $186(11)$ & $32(54)$ & 10MAY-13AUG \\
\hline Caripeta divisata Wlk. & $1(242)$ & & $1(212)$ & 27JUL-07AUG \\
\hline Besma e & $75(36)$ & $90(30)$ & $89(27)$ & 24MAY-14AUG \\
\hline Besma quercivoraria & $279(7)$ & $114(23)$ & $25(62)$ & 29APR-24SEP \\
\hline Lambdina fisc & $15(104)$ & $8(131)$ & )$. & 06SEP-17OCT \\
\hline Lambdina pellucidaria (G.\& R.) & $3(191)$ & $23(78)$ & $13(83)$ & 25APR-13AUG \\
\hline Lambdina fervid & $105(26)$ & $10(120)$ & & 08MAY-29AUG \\
\hline Eusarca confusaria $\mathrm{Hbn}$. & $1(242)$ & $1(224)$ & $2(184)$ & 06JUN-21SEP \\
\hline Tetracis crocallata $\mathrm{Gn}$. & $1(242)$ & $1(224)$ & & 05JUN-06JUL \\
\hline Tetracis cachexiata Gn. & $124(21)$ & $217(7)$ & $180(11)$ & 16MAY-06JUL \\
\hline Eugonobapta nivosaria (C & $12(122)$ & $12(111)$ & $8(106)$ & 02JUL-19JUL \\
\hline Eutrapela clemataria (J.E. Smit & $29(75)$ & $29(67)$ & $8(106)$ & 08APR-08AUG \\
\hline Prochoerodes transversata (Drury) & $36(67)$ & $13(107)$ & $62(37)$ & 02JUL-22OCT \\
\hline Antepione thisoaria (Gn.) & $12(122)$ & & $3(161)$ & 25MAY-15AUG \\
\hline Nematocampa limbata (Haw.) & 3(191) & $4(163)$ & $5(134)$ & 27JUN-24SEP \\
\hline Nemoria lixaria (Gn.) & $0(\quad)$. & $1(224)$ & $0(\quad)$. & 19APR-19APR \\
\hline Nemoria bistriaria Hbn. & $26(80)$ & $24(76)$ & $2(184)$ & 25APR-29AUG \\
\hline Nemo & & $8(131)$ & & 13AUG-13AUG \\
\hline Pleuroprucha insulsaria (Gn.) & $4(179)$ & $7(141)$ & $8(106)$ & 20JUN-25OCT \\
\hline Pleuroprucha asthenaria (Wlk.) & $13(115)$ & $0()$. & )$. & 21SEP-19OCT \\
\hline Cyclophora packardi (Prout) & $3(191)$ & $7(141)$ & $3(161)$ & $\begin{array}{r}\text { 10MAY-02OCT } \\
\text { continued }\end{array}$ \\
\hline
\end{tabular}




\begin{tabular}{|c|c|c|c|c|}
\hline SPECIES & \multicolumn{3}{|c|}{ TOTAL CATCH (RANK) } & $\begin{array}{l}\text { INCLUSIVE } \\
\text { FLIGHT } \\
\text { RANGE }\end{array}$ \\
\hline Cyclophora pendulinaria (Gn.) & $27(78)$ & $28(69)$ & $9(105)$ & 02MAY-29AUG \\
\hline Scopula limboundata (Haw.) & $91(28)$ & $25(75)$ & $19(71)$ & 02JUL-26SEP \\
\hline Dysstroma hersiliata (Gn.) & 0( & $O(\quad)$ & $1(212)$ & 10JUL-10JUL \\
\hline Eulithis diversilineata (Hbn.) & $11(130)$ & $6(151)$ & $5(134)$ & 06JUL-26SEP \\
\hline Eulithis explanata (Wlk.) & $2(215)$ & $0()$. & $0()$. & 06JUL-27JUL \\
\hline Hydriomena divisaria (Wlk.) & $69(42)$ & $17(92)$ & & 25APR-03JUN \\
\hline Hydria prunivorata (Fgn.) & $13(115)$ & 11(118) & $5(134)$ & 12JUN-19JUL \\
\hline Mesoleuca ruficillata (Gn.) & $0()$. & $1(224)$ & $0(\quad)$. & 05JUN-05JUN \\
\hline Anticlea vasiliata $\mathrm{Gn}$. & $2(215)$ & $3(179)$ & $1(212)$ & 25APR-16MAY \\
\hline Xanthorhoe ferrugata (Cl.) & $0(\quad)$. & $1(224)$ & $0(\quad)$. & 02MAY-02MAY \\
\hline Xanthorhoe lacustrata (Gn.) & $5(166)$ & $7(141)$ & .) & 10MAY-10SEP \\
\hline Epirrhoe alternata (Mu"ller) & $0()$. & $0(\quad)$ & $1(212)$ & $12 \mathrm{JUN}-12 \mathrm{JUN}$ \\
\hline Euphyia unangulata (Haw.) & 0( & $0(\quad)$ & $1(212)$ & 21AUG-21AUG \\
\hline Orthonama obstipata (F.) & $2(215)$ & $2(199)$ & $6(124)$ & 06MAY-28AUG \\
\hline Orthonama centrostrigaria (Woll.) & $5(166)$ & $7(141)$ & $11(95)$ & 05JUN-17OCT \\
\hline Hydrelia inornata (Hulst) & $41(64)$ & $135(17)$ & $147(14)$ & 16MAY-09SEP \\
\hline Venusia cambrica Curt. & $0()$. & 2(199) & $0()$. & 05JUN-19JUL \\
\hline Trichodezia albovittata (Gn.) & 0( & $3(179)$ & )$. & 10MAY-30MAY \\
\hline Eubaphe mendica (Wlk.) & $3(191)$ & $1(224)$ & )$. & 30MAY-15AUG \\
\hline Horisme intestinata (Gn.) & $0(\quad)$ & $1(224)$ & $1(212)$ & $12 \mathrm{JUN}-13 \mathrm{AUG}$ \\
\hline Eupithecia miserulata Grt. & $208(10)$ & $163(14)$ & $84(29)$ & 28MAR-21SEP \\
\hline Cladara limitaria (Wlk.) & $5(166)$ & $0()$. & & 08MAY-12MAY \\
\hline Cladara atroliturata (Wlk.) & $4(179)$ & $19(84)$ & $4(147)$ & 08APR-16MAY \\
\hline Lobophora nivigerata Wlk. & $0()$. & $2(199)$ & $0()$. & 10MAY-10MAY \\
\hline Heterophleps refusaria (Wlk.) & $0(\quad)$. & $0()$. & $1(212)$ & 17JUL-17JUL \\
\hline Heterophleps triguttaria H.-S. & $0()$. & $1(224)$ & $4(147)$ & 12JUN-06AUG \\
\hline Dyspteris abortivaria (H.-S.) & $4(179)$ & $1(224)$ & $2(184)$ & 08JUN-30JUL \\
\hline \multicolumn{5}{|l|}{ EPIPLEMIDAE } \\
\hline Calledapteryx dryopte & $1(242)$ & $1(224)$ & $3(161)$ & 30MAY-07AUG \\
\hline \multicolumn{5}{|l|}{ MIMALLONIDAE } \\
\hline Lacosoma chiridota Grt. & $1(242)$ & $3(179)$ & $0(\quad)$. & 05JUN-28JUN \\
\hline Cicinnus melsheimeri (Harr.) & $7(154)$ & $27(72)$ & $17(74)$ & $05 J U N-28 J U N$ \\
\hline \multicolumn{5}{|l|}{ APATELODIDAE } \\
\hline Apatelodes torrefacta (J.E. Smith) & $23(85)$ & $4(163)$ & $12(91)$ & $12 \mathrm{JUN}-08 \mathrm{AUG}$ \\
\hline Olceclostera angelica (Grt.) & $1(242)$ & $0(\quad)$. & $0(\quad)$. & 06JUL-06JUL \\
\hline \multicolumn{5}{|l|}{ LASIOCAMPIDAE } \\
\hline Tolype velleda (Stoll) & $36(67)$ & $14(102)$ & $2(184)$ & 10SEP-01OCT \\
\hline Phyllodesma americana (Harr.) & $2(215)$ & $5(157)$ & $0(\quad)$ & 19APR-12MAY \\
\hline Malacosoma disstria Hbn. & $108(24)$ & $36(60)$ & $146(15)$ & 20JUN-18JUL \\
\hline Malacosoma americanum (F.) & $407(5)$ & $162(15)$ & $193(10)$ & 05JUN-27JUL \\
\hline
\end{tabular}




\begin{tabular}{|c|c|c|c|c|}
\hline SPECIES & \multicolumn{3}{|c|}{ TOTAL CATCH (RANK) } & $\begin{array}{l}\text { INCLUSIVE } \\
\text { FLIGHT } \\
\text { RANGE }\end{array}$ \\
\hline \multicolumn{5}{|l|}{ SATURNIIDAE } \\
\hline Eacles imperialis (Drury) & $1(242)$ & & $3(161)$ & 17JUL-03AUG \\
\hline Dryocampa rubicunda (F.) & $23(85)$ & $4(163)$ & $6(124)$ & 16MAY-08AUG \\
\hline Automeris io (F.) & $16(101)$ & $13(107)$ & $7(116)$ & 24MAY-10JUL \\
\hline Antheraea polyphemus (Cram.) & $43(62)$ & $13(107)$ & $7(116)$ & 10MAY-13AUG \\
\hline Actias luna (L.) & $3(191)$ & $6(151)$ & $5(134)$ & 02MAY-08AUG \\
\hline Callosamia angulifera (Wlk.) & $2(215)$ & $0(\quad)$. & $6(124)$ & 10JUL-08AUG \\
\hline \multicolumn{5}{|l|}{ SPHINGIDAE } \\
\hline Manduca jasminearum (Guer.) & $1(242)$ & $1(224)$ & $0()$. & 10JUL-03AUG \\
\hline Ceratomia undulosa (Wlk.) & $1(242)$ & 0( & $2(184)$ & 10JUL-07AUG \\
\hline Paonias excaecatus (J.E. Smith) & $31(74)$ & $57(45)$ & $78(31)$ & 30MAY-08AUG \\
\hline Paonias myops (J.E. Smith) & $64(44)$ & $44(52)$ & $88(28)$ & 16MAY-15AUG \\
\hline Laothoe juglandis (J.E. Smith) & $1(242)$ & $0(\quad)$. & $4(147)$ & 02JUL-19JUL \\
\hline Pachysphinx modesta (Harr.) & $O(\quad)$. & $0(\quad)$. & $1(212)$ & 10JUL-10JUL \\
\hline \multicolumn{5}{|l|}{ NOTODONTIDAE } \\
\hline Clostera albosigma Fitch & $1(242)$ & 0( & 0( & 03JUN-03JUN \\
\hline Clostera inclusa (Hbn.) & $3(191)$ & $O(\quad)$. & 0( & 03JUN-03AUG \\
\hline Datana ministra (Drury) & $9(142)$ & $24(76)$ & $11(95)$ & 05JUN-03AUG \\
\hline Datana angusii G.\& R. & & $O(\quad)$. & $5(134)$ & 06JUN-17JUL \\
\hline Datana drexelii Hy. Edw. & $1(242)$ & 0( & & 27JUL-27JUL \\
\hline Datana integerrima G.\& R. & $1(242)$ & $O(\quad)$. & 0( & $22 \mathrm{JUN}-22 \mathrm{JUN}$ \\
\hline Nadata gibbosa (J.E. Smith) & $77(35)$ & $84(33)$ & $240(7)$ & 06MAY-26SEP \\
\hline Hyperaeschra georgica (H.-S.) & $10(136)$ & $14(102)$ & $1(212)$ & 02MAY-27JUL \\
\hline Peridea basitriens (Wlk.) & $1(242)$ & 2(199) & $2(184)$ & 10JUL-27JUL \\
\hline Peridea angulosa (J.E. Smith) & $192(12)$ & $59(44)$ & $118(22)$ & 12JUN-28AUG \\
\hline Peridea ferruginea (Pack.) & $5(166)$ & $1(224)$ & 0( & 05JUN-08AUG \\
\hline Pheosia rimosa Pack. & $1(242)$ & & 0( & 08AUG-08AUG \\
\hline Odontosia elegans (Stkr.) & $1(242)$ & $3(179)$ & $5(134)$ & $12 \mathrm{JUN}-03 \mathrm{AUG}$ \\
\hline Nerice bidentata Wlk. & $2(215)$ & $O()$. & $O(\quad)$. & 08AUG-23AUG \\
\hline Ellida caniplaga (Wlk.) & $0(\quad)$. & $5(157)$ & 0( & 19APR-10MAY \\
\hline Gluphisia septentrionis Wlk. & $2(215)$ & $0(\quad)$. & 0( & 08AUG-08AUG \\
\hline Furcula borealis (Guer.-Meneville) & $1(242)$ & $1(224)$ & $1(212)$ & 10MAY-30JUL \\
\hline Symmerista leucitys Franc. & $48(58)$ & $73(36)$ & $119(20)$ & 29MAY-03AUG \\
\hline Dasylophia anguina (J.E. Smith) & $9(142)$ & $4(163)$ & $3(161)$ & 10MAY-17SEP \\
\hline Macrurocampa marthesia (Cram.) & $52(52)$ & $89(31)$ & $110(24)$ & $12 J U N-14 A U G$ \\
\hline Heterocampa obliqua Pack. & $9(142)$ & $7(141)$ & $10(103)$ & 30MAY-15AUG \\
\hline Heterocampa umbrata Wlk. & $3(191)$ & $4(163)$ & $4(147)$ & 10MAY-13AUG \\
\hline Heterocampa guttivitta (Wlk.) & $61(45)$ & $201(8)$ & $297(6)$ & 02MAY-13AUG \\
\hline Heterocampa biundata Wlk. & $23(85)$ & $43(53)$ & $113(23)$ & 24MAY-05SEP \\
\hline Lochmaeus manteo Doubleday & $20(91)$ & $37(58)$ & $60(38)$ & 05JUN-14AUG \\
\hline Lochmaeus bilineata (Pack.) & $0()$. & $O()$. & $1(212)$ & 10JUL-10JUL \\
\hline Schizura ipomoeae Doubleday & $7(154)$ & $17(92)$ & $35(49)$ & 06JUN-05SEP \\
\hline Schizura unicornis (J.E. Smith) & $6(160)$ & $7(141)$ & $0(\quad)$. & $\begin{array}{r}\text { 05JUN-15AUG } \\
\text { continued }\end{array}$ \\
\hline
\end{tabular}




\begin{tabular}{|c|c|c|c|c|}
\hline SPECIES & \multicolumn{3}{|c|}{ TOTAL CATCH (RANK) } & $\begin{array}{l}\text { INCLUSIVE } \\
\text { FLIGHT } \\
\text { RANGE }\end{array}$ \\
\hline Schizura leptinoides (Grt.) & $1(242)$ & $1(224)$ & 1(212) & 05JUN-27JUL \\
\hline Oligocentria semirufescens (Wlk.) & $49(56)$ & $18(90)$ & $32(54)$ & 05JUN-09SEP \\
\hline Oligocentria lignicolor (Wlk.) & $12(122)$ & $2(199)$ & $1(212)$ & 28JUN-23AUG \\
\hline \multicolumn{5}{|l|}{ ARCTIIDAE } \\
\hline Hypoprepia miniata (Kby.) & $14(109)$ & $0(\quad)$. & $13(83)$ & 10JUL-23JUL \\
\hline Hypoprepia fucosa $\mathrm{Hbn}$. & $21(90)$ & $14(102)$ & $0()$. & 10JUL-15AUG \\
\hline Clemensia albata Pack. & $83(32)$ & $312(5)$ & $200(9)$ & 29MAY-110CT \\
\hline Haploa clymene (Brown) & $1(242)$ & $0(\quad)$. & $0(\quad)$. & 08AUG-08AUG \\
\hline Holomelina opella (Grt.) & $0(\quad)$. & 0( & $1(212)$ & $20 \mathrm{JUN}-20 \mathrm{JUN}$ \\
\hline Pyrrharctia isabella (J.E. Smith) & $3(191)$ & $0()$. & $0(\quad)$. & 28JUN-28JUN \\
\hline Spilosoma latipennis Stretch & $1(242)$ & 0( & $1(212)$ & $12 J U N-12 J U N$ \\
\hline Spilosoma virginica (F.) & $3(191)$ & 2(199) & 1(212) & 10MAY-21AUG \\
\hline Hyphantria cunea (Drury) & $153(16)$ & $169(13)$ & $13(83)$ & 10MAY-18JUL \\
\hline Apantesis phalerata (Harr.) & $5(166)$ & $1(224)$ & $0(\quad)$. & 10MAY-28JUN \\
\hline Apantesis nais (Drury) & $0()$. & $0(\quad)$ & $1(212)$ & 16MAY-16MAY \\
\hline Apantesis figurata (Drury) & $1(242)$ & 0( & $0(\quad)$ & $28 \mathrm{JUN}-28 \mathrm{JUN}$ \\
\hline Halysidota tessellaris (J.E. Smith) & $698(2)$ & $149(16)$ & $144(16)$ & 30MAY-15AUG \\
\hline Lophocampa caryae Harr. & $2(215)$ & $63(42)$ & $34(51)$ & 29MAY-28JUN \\
\hline Cycnia tenera Hbn. & $1(242)$ & $2(199)$ & $2(184)$ & $12 J U N-15 A U G$ \\
\hline Euchaetes & $3(191)$ & $0(\quad)$. & $1(212)$ & 28JUN-17JUL \\
\hline Cisseps fulvicollis (Hbn.) & $1(242)$ & $0(\quad)$. & $0(\quad)$. & $28 \mathrm{JUN}-28 \mathrm{JUN}$ \\
\hline \multicolumn{5}{|l|}{ LYMANTRIIDAE } \\
\hline Dasychira dorsipenn & & $0(\quad)$. & $67(33)$ & 20JUN-23JUL \\
\hline Dasychira obliquata (G.\& R.) & 0( & $4(163)$ & 1(212) & 23JUL-13AUG \\
\hline Dasychira spp. & $75(36)$ & $47(50)$ & $53(40)$ & 12JUN-24SEP \\
\hline Orgyia leucostigma (J.E. Smith) & $173(14)$ & $37(58)$ & $163(13)$ & $28 \mathrm{JUN}-30 \mathrm{OCT}$ \\
\hline \multicolumn{5}{|l|}{ NOCTUIDAE } \\
\hline Idia amer & $15(104)$ & $12(111)$ & $32(54)$ & 16MAY-19OCT \\
\hline Idia aemula Hbn. & $346(6)$ & $38(57)$ & $45(45)$ & 12JUN-30OCT \\
\hline Idia rotundalis (Wlk.) & $205(11)$ & $231(6)$ & $65(34)$ & 10JUL-21SEP \\
\hline Idia diminuendis (B.\& McD.) & $O(\quad)$ & $3(179)$ & $2(184)$ & 23JUL-13AUG \\
\hline Idia scobialis (Grt.) & $4(179)$ & $3(179)$ & $4(147)$ & 10JUL-21SEP \\
\hline Idia lubricalis (Gey.) & $15(104)$ & $0()$. & 2(184) & 13JUL-29AUG \\
\hline Phalaenophana pyramusalis (Wlk.) & $9(142)$ & $4(163)$ & $13(83)$ & 30MAY-11SEP \\
\hline Zanclognatha lituralis (Hbn.) & $8(149)$ & $39(56)$ & $19(71)$ & 27JUN-24JUL \\
\hline Zanclognatha laevigata (Grt.) & $144(18)$ & $41(54)$ & $48(43)$ & 20JUN-06SEP \\
\hline Zanclognatha pedipilalis (Gn.) & 13(115) & & $3(161)$ & 20JUN-13SEP \\
\hline Zanclognatha protumnusalis (Wlk.) & $7(154)$ & $0()$. & $O()$. & 03AUG-15AUG \\
\hline Zanclognatha cruralis (Gn.) & $1(242)$ & $12(111)$ & $0(\quad)$. & 05JUN-19JUL \\
\hline Zanclognatha jacchusalis (Wlk.) & $5(166)$ & $o(\quad)$ & $0()$. & 28JUN-08AUG \\
\hline Zanclognatha ochreipennis (Grt.) & $214(9)$ & $70(39)$ & $42(47)$ & 20JUN-02OCT \\
\hline Chytolita morbidalis (Gn.) & $46(60)$ & $126(19)$ & $31(57)$ & $\begin{array}{l}\text { 29MAY-13JUL } \\
\text { continued }\end{array}$ \\
\hline
\end{tabular}




\begin{tabular}{|c|c|c|c|c|}
\hline SPECIES & \multicolumn{3}{|c|}{ TOTAL CATCH (RANK) } & $\begin{array}{l}\text { INCLUSIVE } \\
\text { FLIGHT } \\
\text { RANGE } \\
\end{array}$ \\
\hline Phalaenostola metonalis (Wlk.) & $3(191)$ & $O(\quad)$. & $3(161)$ & 12JUN-24SEP \\
\hline Phalaenostola larentioides Grt. & $9(142)$ & $1(224)$ & $3(161)$ & 03JUN-23AUG \\
\hline Tetanolita mynesalis (Wlk.) & $0(\quad)$. & $0()$. & $4(147)$ & 17JUL-30JUL \\
\hline Bleptina caradrinalis $\mathrm{Gn}$. & $2(215)$ & $0(\quad)$. & 0( & 03JUN-08JUN \\
\hline Renia factiosalis (Wlk.) & $43(62)$ & 0( & $o()$. & 03AUG-15AUG \\
\hline Renia nemoralis B.\& McD. & $0(\quad)$. & 0( & $1(212)$ & 23JUL-23JUL \\
\hline Renia discoloralis $\mathrm{Gn}$. & $1(242)$ & $31(66)$ & $5(134)$ & 06JUL-06SEP \\
\hline Renia sobrialis (Wlk.) & $4(179)$ & $3(179)$ & $0()$. & 06AUG-15AUG \\
\hline Palthis angulalis (Hbn.) & $8(149)$ & $0(\quad)$. & $2(184)$ & 08JUN-15AUG \\
\hline Palthis asopialis (Gn.) & $0(\quad)$. & 0( & $1(212)$ & 24SEP-24SEP \\
\hline Rivula propinqualis $\mathrm{G}$. & .) & $3(179)$ & $1(212)$ & 05JUN-06SEP \\
\hline Bomolocha baltimoralis (Gn.) & $116(22)$ & $104(25)$ & $107(25)$ & 29APR-26SEP \\
\hline Bomolocha palparia (Wlk.) & $1(242)$ & $0()$. & $0()$. & 13JUL-13JUL \\
\hline Bomolocha abalienalis (Wlk.) & $2(215)$ & 0( & .) & 06JUL-03AUG \\
\hline Bomolocha deceptalis (Wlk.) & $0(\quad)$. & $5(157)$ & $1(212)$ & 06MAY-05JUN \\
\hline Bomolocha madefactalis ( $\mathrm{Gn}$. ) & $0(\quad)$. & $1(224)$ & & 05JUN-05JUN \\
\hline Bomolocha edictalis (Wlk.) & $7(154)$ & $1(224)$ & $2(184)$ & 03JUL-08AUG \\
\hline Hypena humuli Harr. & $1(242)$ & 2(199) & $0(\quad)$ & 25APR-03AUG \\
\hline Plathypena scabra (F.) & $12(122)$ & $8(131)$ & $7(116)$ & 23AUG-30OCT \\
\hline Pangrapta decoralis Hbn. & $20(91)$ & $28(69)$ & $21(68)$ & 23MAY-09SEP \\
\hline Metalectra discalis (Grt.) & $0(\quad)$. & $2(199)$ & $2(184)$ & $12 J U N-13 A U G$ \\
\hline Scolecocampa liburna (Gey.) & $2(215)$ & & $3(161)$ & 17JUL-23AUG \\
\hline Scoliopteryx libatrix (L.) & $0(\quad)$. & $1(224)$ & $0(\quad)$. & 10JUL-10JUL \\
\hline Anticarsia gemmatalis $\mathrm{Hbn}$. & $0()$. & & $2(184)$ & 02OCT-02OCT \\
\hline Panopoda rufimargo (Hbn.) & $26(80)$ & 2(199) & $6(124)$ & 28JUN-08AUG \\
\hline Phoberia atomaris $\mathrm{Hbn}$. & $33(71)$ & $13(107)$ & $3(161)$ & 08APR-25MAY \\
\hline Cissusa spadix (Cram.) & $7(154)$ & $8(131)$ & $0()$. & 04MAY-25MAY \\
\hline Zale lunata (Drury) & $1(242)$ & $o()$. & $1(212)$ & $10 \mathrm{OCT}-28 \mathrm{OCT}$ \\
\hline Zale galbanata (Morr.) & $1(242)$ & $0()$. & $0()$. & 08MAY-08MAY \\
\hline Zale aeruginosa (Gn.) & $1(242)$ & 0( & $0(\quad)$. & $22 J U N-22 J U N$ \\
\hline Zale undularis (Drury) & $1(242)$ & 0( & $O(\quad)$. & $22 J U N-22 J U N$ \\
\hline Zale minerea (Gn.) & $53(51)$ & $85(32)$ & $13(83)$ & 08APR-08AUG \\
\hline Zale lunifera (Hbn.) & $12(122)$ & $82(34)$ & $13(83)$ & 02APR-03JUN \\
\hline Zale unilineata (Grt.) & $4(179)$ & $8(131)$ & & 10MAY-25MAY \\
\hline Euparthenos nubilis (Hbn.) & $5(166)$ & $0(\quad)$. & $2(184)$ & 16MAY-29AUG \\
\hline Allotria elonympha (Hbn.) & $14(109)$ & $4(163)$ & $4(147)$ & 05JUN-26SEP \\
\hline Parallelia bistriaris Hbn. & $101(27)$ & $19(84)$ & $21(68)$ & 10MAY-10SEP \\
\hline Euclidia cuspidea (Hbn.) & & $1(224)$ & $0()$. & 05JUN-05JUN \\
\hline Caenurgina erechtea (Cram.) & $1(242)$ & $0(\quad)$. & 0( & $28 J U N-28 J U N$ \\
\hline Catocala retecta Grt. & $4(179)$ & $1(224)$ & $4(147)$ & 28AUG-02OCT \\
\hline Catocala vidua (J.E. Smith) & $1(242)$ & $O(\quad)$. & $0(\quad)$. & 29AUG-29AUG \\
\hline Catocala palaeogama Gn. & $2(215)$ & $0(\quad)$ & 0( & 23AUG-23AUG \\
\hline Catocala subnata Grt. & $0()$. & $1(224)$ & 0( & $23 A U G-23 A U G$ \\
\hline Catocala ilia (Cram.) & $6(160)$ & $19(84)$ & $10(103)$ & 03JUL-26SEP \\
\hline Catocala relicta Wlk. & $1(242)$ & $o()$. & $1(212)$ & $\begin{array}{l}\text { 28AUG-26SEP } \\
\text { continued }\end{array}$ \\
\hline
\end{tabular}




\begin{tabular}{|c|c|c|c|c|}
\hline SPECIES & \multicolumn{3}{|c|}{ TOTAL CATCH (RANK) } & $\begin{array}{l}\text { INCLUSIVE } \\
\text { FLIGHT } \\
\text { RANGE } \\
\end{array}$ \\
\hline Catocala sordida Grt. & $6(160)$ & $0(\quad)$. & 0( & 03AUG-08AUG \\
\hline Catocala gracilis Edw. & & 2(199) & & 19JUL-13AUG \\
\hline Catocala andromedae $\mathrm{Gn}$. & $3(191)$ & & $1(212)$ & 30JUL-08AUG \\
\hline Catocala ultronia (Hbn.) & $12(122)$ & $27(72)$ & $11(95)$ & 17JUL-01OCT \\
\hline Catocala grynea (Cram.) & $1(242)$ & $1(224)$ & $O(\quad)$. & 15AUG-06SEP \\
\hline Catocala blandula Hulst & $2(215)$ & & $2(184)$ & 06JUL-08AUG \\
\hline Catocala similis Edw. & $1(242)$ & $0(\quad)$. & 1(212) & 17JUL-03AUG \\
\hline Catocala micronympha $\mathrm{Gn}$. & $2(215)$ & $1(224)$ & & 27JUL-15AUG \\
\hline Catocala amica (Hbn.) & $26(80)$ & $0(\quad)$. & $2(184)$ & 23JUL-10SEP \\
\hline Allagrapha aerea (Hbn.) & $1(242)$ & & & 03AUG-03AUG \\
\hline Chrysanympha formosa (Grt.) & $3(191)$ & $6(151)$ & $1(212)$ & 05JUN-18JUL \\
\hline Eosphoropteryx thyatyroides (Gn.) & $1(242)$ & $1(224)$ & $1(212)$ & 03AUG-24SEP \\
\hline Autographa precationis (Gn.) & $3(191)$ & $2(199)$ & $6(124)$ & 03JUN-24SEP \\
\hline Autographa ampla (Wlk.) & & $1(224)$ & 0( & 06AUG-06AUG \\
\hline Anagrapha falcifera (Kby.) & $1(242)$ & $3(179)$ & 0( & 05JUN-28JUN \\
\hline Paectes oculatrix (Gn.) & $1(242)$ & 0( & 0( & 15AUG-15AUG \\
\hline Baileya doubledayi (Gn.) & $1(242)$ & & 0( & 03AUG-03AUG \\
\hline Baileya ophthalmica (Gn.) & 0( & 14(102) & 2(184) & 10MAY-06JUN \\
\hline Baileya levitans (Sm.) & 14(109) & & $4(147)$ & 08MAY-27JUL \\
\hline Meganola minuscula (Zell.) & $22(88)$ & $7(141)$ & 0( & 25APR-25MAY \\
\hline Nola triquetrana (Fitch) & $0()$. & & $11(95)$ & 02APR-30JUL \\
\hline Hyperstrotia pervertens (B.\& McD.) & & $1(224)$ & $2(184)$ & 17JUL-06AUG \\
\hline Hyperstrotia secta (Grt.) & $1(242)$ & $15(96)$ & $51(42)$ & 20JUN-03AUG \\
\hline Lithacodia muscosula (Gn.) & $3(191)$ & $O($ & $3(161)$ & $12 \mathrm{JUN}-29 \mathrm{AUG}$ \\
\hline Lithacodia albidula (Gn.) & $1(242)$ & 0( & $0(\quad)$. & 08AUG-08AUG \\
\hline Lithacodia synochitis (G.\& R.) & 0( & & $1(212)$ & 02JUL-02JUL \\
\hline Lithacodia musta (G.\& R.) & )$. & 0( & $4(147)$ & 27JUN-17JUL \\
\hline Lithacodia carneola (Gn.) & $5(166)$ & $1(224)$ & $1(212)$ & 05JUN-03AUG \\
\hline Cerma cerintha (Tr.) & $18(95)$ & $3(179)$ & $3(161)$ & $12 \mathrm{JUN}-08 \mathrm{AUG}$ \\
\hline Tarachidia candefacta (Hbn.) & $1(242)$ & 0( & 0( & $28 \mathrm{JUN}-28 \mathrm{JUN}$ \\
\hline Colocasia propinquilinea (Grt.) & $13(115)$ & $15(96)$ & $5(134)$ & 19APR-15AUG \\
\hline Charadra deridens (Gn.) & $2(215)$ & 0( & $0(\quad)$. & 25MAY-27JUL \\
\hline Raphia frater Grt. & $3(191)$ & & 0( & 22JUN-13JUL \\
\hline Acronicta americana (Harr.) & $12(122)$ & $5(157)$ & $12(91)$ & 12JUN-07AUG \\
\hline Acronicta dactylina Grt. & $1(242)$ & & 0( & $22 \mathrm{JUN}-22 \mathrm{JUN}$ \\
\hline Acronicta innotata Gn. & $5(166)$ & 0 & $6(124)$ & 27JUN-08AUG \\
\hline Acronicta radcliffei (Harv.) & $0(\quad)$. & 2(199) & $1(212)$ & 25APR-23AUG \\
\hline Acronicta funeralis G.\& R. & 0( & $1(224)$ & & 10MAY-10MAY \\
\hline Acronicta hasta Gn. & $47(59)$ & $19(84)$ & $8(106)$ & 02MAY-23AUG \\
\hline Acronicta morula G.\& $\mathbf{R}$. & & $1(224)$ & 0( & 02MAY-02MAY \\
\hline Acronicta interrupta $\mathrm{Gn}$. & $1(242)$ & $1(224)$ & 0( & 16MAY-23AUG \\
\hline Acronicta lobeliae Gn. & $2(215)$ & $4(163)$ & 0( & 10MAY-23AUG \\
\hline Acronicta fragilis $\mathrm{Gn}$. & $85(31)$ & $23(78)$ & $52(41)$ & 10MAY-06AUG \\
\hline Acronicta ovata Grt. & $177(13)$ & $57(45)$ & $177(12)$ & 16MAY-05SEP \\
\hline Acronicta modica Wlk. & $49(56)$ & $10(120)$ & $4(147)$ & $\begin{array}{r}\text { 05JUN-15AUG } \\
\text { continuea }\end{array}$ \\
\hline
\end{tabular}




\begin{tabular}{|c|c|c|c|c|}
\hline SPECIES & \multicolumn{3}{|c|}{ TOTAL CATCH (RANK) } & $\begin{array}{l}\text { INCLUSIVE } \\
\text { FLIGHT } \\
\text { RANGE }\end{array}$ \\
\hline Acronicta haesitata (Grt.) & $3(191)$ & $9(125)$ & $35(49)$ & 29MAY-13AUG \\
\hline Acronicta tristis Sm. & $27(78)$ & 0( & 0( & $22 J U N-03 A U G$ \\
\hline Acronicta increta Morr. & $60(46)$ & $10(120)$ & $12(91)$ & 29MAY-23AUG \\
\hline Acronicta inclara Sm. & $18(95)$ & $12(111)$ & $34(51)$ & 05JUN-03AUG \\
\hline Acronicta retardata (Wlk.) & $33(71)$ & $10(120)$ & $13(83)$ & 05JUN-14AUG \\
\hline Acronicta caesarea Sm. & $0(\quad)$. & $0()$. & $22(64)$ & $12 \mathrm{JUN}-30 \mathrm{JUL}$ \\
\hline Acronicta impleta WIk. & $1(242)$ & $5(157)$ & $1(212)$ & 02MAY-15AUG \\
\hline Acronicta lithospila Grt. & $1(242)$ & 0( & $0(\quad)$. & 13JUL-13JUL \\
\hline Polygrammate hebraeicum $\mathrm{Hbn}$. & $50(54)$ & $19(84)$ & $27(60)$ & 05JUN-29AUG \\
\hline Eudryas grata (F.) & $6(160)$ & $7(141)$ & $O(\quad)$. & $28 J U N-15 A U G$ \\
\hline Apamea amputatrix (Fitch) & $1(242)$ & 0( & 0( & $28 \mathrm{JUN}-28 \mathrm{JUN}$ \\
\hline Agroperina dubitans (Wlk.) & $1(242)$ & .) & 0( & 23AUG-23AUG \\
\hline Agroperina helva (Grt.) & $0(\quad)$. & $2(199)$ & 0( & 28AUG-28AUG \\
\hline Oligia modica (Gn.) & $O(\quad)$ & $0(\quad)$. & $1(212)$ & 21AUG-21AUG \\
\hline Oligia crytora (Franc.) & $2(215)$ & 0( & $0(\quad)$. & 13JUL-13JUL \\
\hline Oligia mactata (Gn.) & $1(242)$ & 0( & $1(212)$ & 26SEP-02OCT \\
\hline Oligia illocata (Wlk.) & $17(100)$ & $19(84)$ & $7(116)$ & 05SEP-17OCT \\
\hline Amphipoea americana (Speyer) & $1(242)$ & & $0(\quad)$. & 03AUG-03AUG \\
\hline Papaipema lysimachiae Bird & & $1(224)$ & 0( & 24SEP-24SEP \\
\hline Papaipema inquaesita (G.\& R.) & $1(242)$ & $0(\quad)$ & 0( & 26SEP-26SEP \\
\hline Papaipema baptisiae (Bird) & $0(\quad)$. & $2(199)$ & 0( & 10SEP-24SEP \\
\hline Papaipema marginidens (Gn.) & $0(\quad)$. & $1(224)$ & 0( & 11OCT-11OCT \\
\hline Papaipema cerussata (Grt.) & $1(242)$ & 0( & 0( & 17OCT-17OCT \\
\hline Papaipema unimoda (Sm.) & $1(242)$ & 0( & 0( & 26SEP-26SEP \\
\hline Achatodes zeae (Harr.) & & 0( & $1(212)$ & 21AUG-21AUG \\
\hline Iodopepla u-album (Gn.) & $1(242)$ & 0( & $0(\quad)$ & 03AUG-03AUG \\
\hline Euplexia benesimilis McD. & $28(76)$ & $36(60)$ & $15(79)$ & 10MAY-26SEP \\
\hline Phlogophora iris Gn. & $9(142)$ & $32(65)$ & $8(106)$ & 16MAY-28AUG \\
\hline Phlogophora periculosa $\mathrm{Gn}$. & $39(65)$ & $23(78)$ & $7(116)$ & 15AUG-21SEP \\
\hline Chytonix palliatricula $(\mathrm{Gn}$.) & $34(69)$ & $29(67)$ & $14(82)$ & 16MAY-15AUG \\
\hline Hyppa xylinoides (Gn.) & $1(242)$ & $1(224)$ & 0( & 03AUG-06AUG \\
\hline Nedra ramosula (Gn.) & $4(179)$ & 0( & 0( & 27APR-26SEP \\
\hline Phosphila turbulenta Hbn. & $34(69)$ & $52(47)$ & $83(30)$ & $12 \mathrm{JUN}-03 \mathrm{AUG}$ \\
\hline Phosphila miselioides (Gn.) & $14(109)$ & $11(118)$ & $17(74)$ & 05JUN-19SEP \\
\hline Callopistria mollissima (Gn.) & $52(52)$ & $36(60)$ & $33(53)$ & 10MAY-09SEP \\
\hline Amphipyra pyramidoides $\mathrm{Gn}$. & 14(109) & $26(74)$ & $16(76)$ & 23JUL-30OCT \\
\hline Amphipyra tragopoginis $(\mathrm{Cl}$.) & $0()$. & $1(224)$ & $0(\quad)$. & 10JUL-10JUL \\
\hline Anorthodes tarda (Gn.) & $19(94)$ & $67(40)$ & $8(106)$ & 10MAY-26SEP \\
\hline Balsa labecula (Grt.) & $1(242)$ & $3(179)$ & $0(\quad)$. & 30MAY-13JUL \\
\hline Spodoptera frugiperda (J.E. Smith) & $3(191)$ & $0()$. & $3(161)$ & 28AUG-17OCT \\
\hline Spodoptera ornithogalli (Gn.) & $1(242)$ & $1(224)$ & 0( & 26SEP-11OCT \\
\hline Elaphria versicolor (Grt.) & $0()$. & $2(199)$ & & $12 J U N-12 J U N$ \\
\hline Elaphria festivoides (Gn.) & $11(130)$ & $102(26)$ & $8(106)$ & 10MAY-06JUL \\
\hline Elaphria grata Hbn. & $1(242)$ & $2(199)$ & $6(124)$ & 20JUN-09SEP \\
\hline Galgula partita $\mathrm{Gn}$. & $1(242)$ & $1(224)$ & $2(184)$ & $\begin{array}{r}12 \mathrm{JUN}-22 \mathrm{OCT} \\
\text { continued }\end{array}$ \\
\hline
\end{tabular}




\begin{tabular}{|c|c|c|c|c|}
\hline SPECIES & \multicolumn{3}{|c|}{ TOTAL CATCH (RANK) } & $\begin{array}{l}\text { INCLUSIVE } \\
\text { FLIGHT } \\
\text { RANGE } \\
\end{array}$ \\
\hline Perigea xanthioides Gn. & $2(215)$ & $0(\quad)$. & $O()$. & $28 \mathrm{JUN}-03 \mathrm{AUG}$ \\
\hline Platysenta vecors (Gn.) & $60(46)$ & $4(163)$ & $4(147)$ & 02MAY-26SEP \\
\hline Platysenta sutor (Gn.) & $1(242)$ & 0 & $1(212)$ & 22JUN-05SEP \\
\hline Lithophane semiusta Grt. & $1(242)$ & & $1(212)$ & 08APR-21SEP \\
\hline Lithophane innominata (Sm.) & & $1(224)$ & $1(212)$ & 28MAR-02APR \\
\hline Lithophane hemina Grt. & $4(179)$ & $9(125)$ & $3(161)$ & 19MAR-17SEP \\
\hline Lithophane signosa (Wlk.) & $1(242)$ & $0()$. & $0(\quad)$ & 26SEP-26SEP \\
\hline Lithophane antennata (Wlk.) & $1(242)$ & $1(224)$ & $o($ & 28MAR-04MAY \\
\hline Lithophane grotei Riley & $0(\quad)$. & $2(199)$ & $1(212)$ & 28MAR-12APR \\
\hline Lithophane unimoda (Lint.) & $0(\quad)$. & 0( & $2(184)$ & 02APR-08APR \\
\hline Pyreferra hesperidago (Gn.) & & $4(163)$ & $8(106)$ & 19MAR-29APR \\
\hline Pyreferra citrombra Franc. & $1(242)$ & $9(125)$ & $6(124)$ & 19MAR-12MAY \\
\hline Eupsilia n. sp. & $1(242)$ & $0(\quad)$. & $0(\quad)$. & 27APR-27APR \\
\hline Eupsilia morrisoni (Grt.) & $1(242)$ & $4(163)$ & $1(212)$ & 19MAR-110CT \\
\hline Epiglaea decliva (Grt.) & $10(136)$ & $1(224)$ & $11(95)$ & $12 \mathrm{OCT}-30 \mathrm{OCT}$ \\
\hline Chaetaglaea sericea (Morr.) & $1(242)$ & $0(\quad)$. & $0(\quad)$. & 17OCT-17OCT \\
\hline Eucirroedia pampina (Gn.) & & 0( & $1(212)$ & $100 C T-100 C T$ \\
\hline Sunira bicolorago (Gn.) & $32(73)$ & $65(41)$ & $21(68)$ & 28AUG-31OCT \\
\hline Anathix ralla (G.\& R.) & $38(66)$ & & $0()$. & 23AUG-17OCT \\
\hline Eutolype rolandi Grt. & $0(\quad)$. & $2(199)$ & $1(212)$ & 08APR-19APR \\
\hline Copipanolis styracis (Gn.) & $8(149)$ & $8(131)$ & $11(95)$ & 27MAR-27APR \\
\hline Psaphida resumens Wlk. & $10(136)$ & $33(64)$ & $1(212)$ & 15APR-27APR \\
\hline Psaphida thaxteriana (Grt.) & $0()$. & $8(131)$ & $0(\quad)$. & 28MAR-28MAR \\
\hline Polia nimbosa (Gn.) & $55(49)$ & $35(63)$ & $126(19)$ & $12 \mathrm{JUN}-03 \mathrm{AUG}$ \\
\hline Polia imbrifera & $1(242)$ & $3(179)$ & $3(161)$ & 05JUN-02JUL \\
\hline Polia detracta (Wlk.) & $0()$. & $106(24)$ & $25(62)$ & 05JUN-17JUL \\
\hline Polia goodelli (Grt.) & 0( & 1(224) & $0(\quad)$. & $12 \mathrm{JUN}-12 \mathrm{JUN}$ \\
\hline Polia latex (Gn.) & $131(20)$ & 79 ( 35$)$ & $94(26)$ & 24MAY-29AUG \\
\hline Lacanobia legitima (Grt.) & $1(242)$ & & & 13JUL-13JUL \\
\hline Hadena ectypa (Morr.) & $0(\quad)$. & & $1(212)$ & 10JUL-10JUL \\
\hline Lacinipolia renigera (Steph.) & $1(242)$ & $1(224)$ & & 28JUN-01OCT \\
\hline Lacinipolia lorea (Gn.) & $1(242)$ & $0(\quad)$ & $0()$. & 08JUN-08JUN \\
\hline Pseudaletia unipuncta (Haw.) & $9(142)$ & $15(96)$ & $5(134)$ & 25APR-26SEP \\
\hline Leucania phragmatidicola Gn. & $12(122)$ & & $1(212)$ & $06 \mathrm{JUN}-28 \mathrm{JUN}$ \\
\hline Leucania multilinea Wlk. & $1(242)$ & 0( & 0( & $22 \mathrm{JUN}-22 \mathrm{JUN}$ \\
\hline Leucania lapidaria (Grt.) & $5(166)$ & & 0( & $22 \mathrm{JUN}-28 \mathrm{JUN}$ \\
\hline Leucania ursula (Fbs.) & $1(242)$ & $1(224)$ & $1(212)$ & 28JUN-10JUL \\
\hline Orthosia rubescens (Wlk.) & $11(130)$ & $93(29)$ & $13(83)$ & 08APR-25MAY \\
\hline Orthosia hibisci (Gn.) & $3(191)$ & $15(96)$ & $15(79)$ & 02APR-27APR \\
\hline Crocigrapha normani (Grt.) & $16(101)$ & $23(78)$ & $0()$. & 19APR-25MAY \\
\hline Himella intractata (Morr.) & $1(242)$ & $0(\quad)$. & 0( & 08MAY-08MAY \\
\hline Egira alternans (Wik.) & $2(215)$ & $4(163)$ & $3(161)$ & 08APR-16MAY \\
\hline Achatia distincta Hbn. & $3(191)$ & $12(111)$ & $0()$. & 19APR-18MAY \\
\hline Morrisonia evicta (Grt.) & $1(242)$ & 0( & 0( & 18MAY-18MAY \\
\hline Morrisonia confusa ( $\mathrm{Hbn}$.) & $79(34)$ & $119(22)$ & 0( & $\begin{array}{r}02 \mathrm{MAY}-12 \mathrm{JUN} \\
\text { continued }\end{array}$ \\
\hline
\end{tabular}




\begin{tabular}{|c|c|c|c|c|}
\hline SPECIES & \multicolumn{3}{|c|}{ TOTAL CATCH (RANK) } & $\begin{array}{l}\text { INCLUSIVE } \\
\text { FLIGHT } \\
\text { RANGE }\end{array}$ \\
\hline Nephelodes minians Gn. & $28(76)$ & $28(69)$ & $7(116)$ & 06SEP-26SEP \\
\hline Homorthodes furfurata (Grt.) & $6(160)$ & $3(179)$ & $1(212)$ & 06JUL-27JUL \\
\hline Protorthodes oviduca (Gn.) & $1(242)$ & & $0(\quad)$ & 25MAY-25MAY \\
\hline Pseudorthodes vecors (Gn.) & $11(130)$ & $3(179)$ & $11(95)$ & 16MAY-13AUG \\
\hline Orthodes crenulata (Butler) & $2(215)$ & $0(\quad)$. & $O(\quad)$. & 18JUL-23AUG \\
\hline Orthodes cynica (Gn.) & $252(8)$ & $188(10)$ & $137(17)$ & 16MAY-18JUL \\
\hline Agrotis venerabilis Wlk. & $2(215)$ & $1(224)$ & $O(\quad)$. & 10SEP-26SEP \\
\hline Agrotis ipsilon (Hufn.) & $4(179)$ & $3(179)$ & $3(161)$ & 23JUL-28OCT \\
\hline Ochropleura plecta (L.) & $0(\quad)$. & $1(224)$ & $1(212)$ & 29MAY-06SEP \\
\hline Peridroma saucia (Hbn.) & $2(215)$ & $1(224)$ & $4(147)$ & 12MAY-17SEP \\
\hline Diarsia jucunda (Wlk.) & $6(160)$ & & $1(212)$ & 10JUL-03AUG \\
\hline Spaelotis clandestina (Harr.) & $0(\quad)$. & $2(199)$ & $1(212)$ & $12 J U N-10 J U L$ \\
\hline Graphiphora haruspica (Grt.) & $1(242)$ & $0(\quad)$. & $0(\quad)$. & 03AUG-03AUG \\
\hline Xestia dolosa Franc. & 14(109) & $18(90)$ & $8(106)$ & 16MAY-26SEP \\
\hline Xestia normaniana (Grt.) & $13(115)$ & $0(\quad)$. & $1(212)$ & 23AUG-09SEP \\
\hline Xestia smithii (Snell.) & $2(215)$ & $0(\quad)$. & $1(212)$ & 05SEP-09SEP \\
\hline Xestia bicarnea (Gn.) & $16(101)$ & $9(125)$ & $2(184)$ & 06AUG-26SEP \\
\hline Xestia badinodis (Grt.) & & $3(179)$ & $0(\quad)$. & 24SEP-01OCT \\
\hline Cerastis tenebrifera (Wlk.) & $1(242)$ & $1(224)$ & 0( & 14APR-19APR \\
\hline Anaplectoides prasina (D.\& S.) & & $0(\quad)$. & $1(212)$ & 17JUL-17JUL \\
\hline Eueretagrotis perattenta (Grt.) & $1(242)$ & $8(131)$ & $2(184)$ & 03JUL-24SEP \\
\hline Eueretagrotis attenta (Grt.) & $8(149)$ & $0(\quad)$. & $1(212)$ & 10JUL-08AUG \\
\hline Heptagrotis phyllophora (Grt.) & $5(166)$ & $2(199)$ & $2(184)$ & 06JUL-03AUG \\
\hline Abagrotis alternata (Grt.) & $66(43)$ & $16(94)$ & & 18JUL-26SEP \\
\hline Heliothis zea (Boddie) & $3(191)$ & $0(\quad)$ & $2(184)$ & 21SEP-28OCT \\
\hline
\end{tabular}



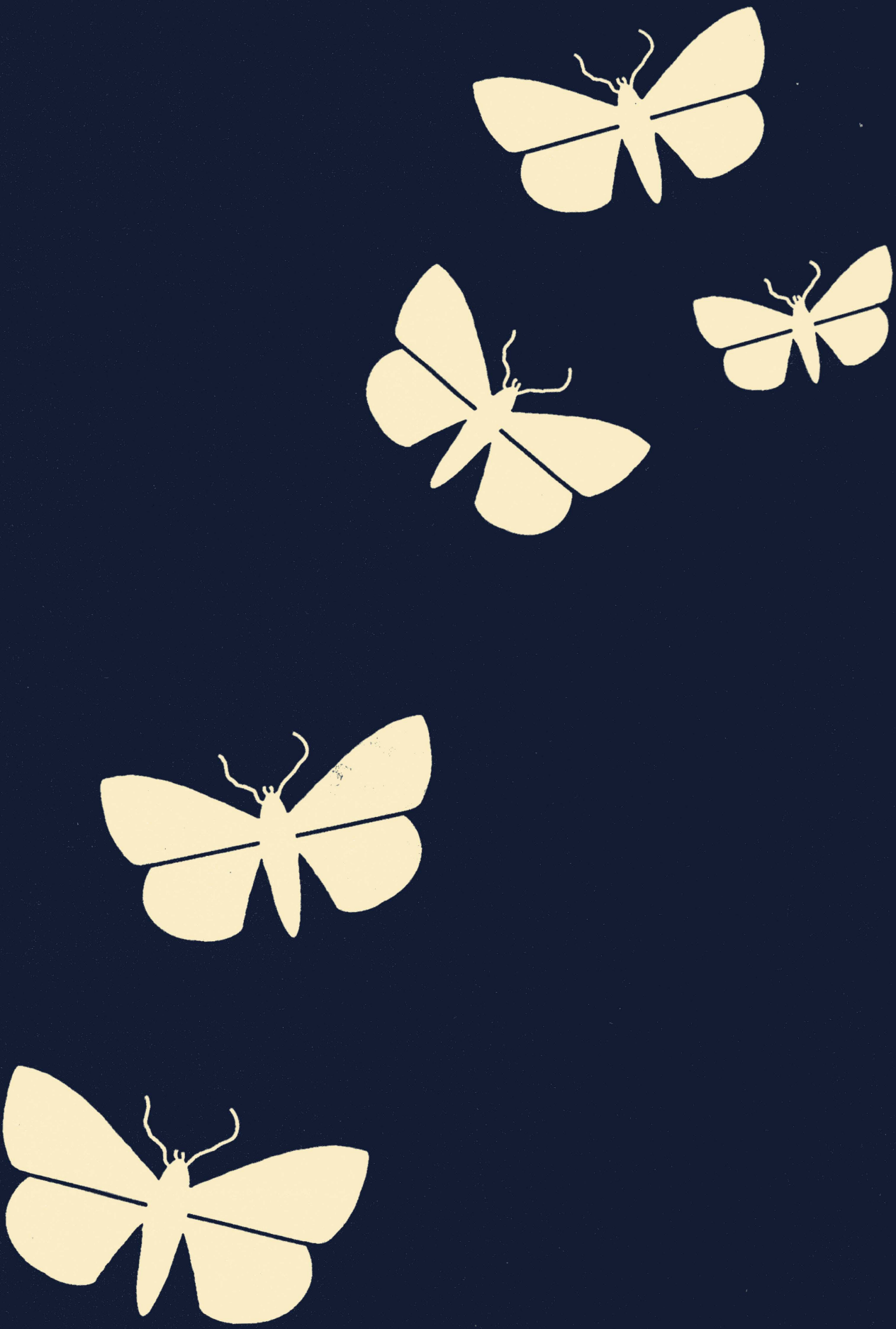